\title{
A Study on Phyllanthus amarus; Pharmacognostic, Mycobactericidal and Mutagenic Properties
}

\author{
Emelia Oppong Bekoe ${ }^{1, *}$, Cindy Kitcher', Philip Debrah², Patrick Amoateng ${ }^{3}$, Paul Owusu Donkor', Sarfoa \\ Martinson ${ }^{1}$
}

Emelia Oppong Bekoe ${ }^{1, *}$, Cindy

Kitcher ${ }^{1}$, Philip Debrah ${ }^{2}$, Patrick

Amoateng ${ }^{3}$, Paul Owusu Donkor', Sarfoa Martinson'

'Department of Pharmacognosy and Herbal Medicine, School of Pharmacy, University of Ghana, GHANA.

${ }^{2}$ Department of Pharmaceutics and

Microbiology, School of Pharmacy, University of Ghana, GHANA.

${ }^{3}$ Department of Pharmacology and

Toxicology, School of Pharmacy, University of Ghana, GHANA.

\section{Correspondence}

\section{Emelia Oppong Bekoe}

Department of Pharmacognosy and Herbal Medicine, School of Pharmacy, University of Ghana, GHANA.

Phone no: +233-265676929

E-mail: eoppongbekoe@ug.edu.gh

History

- Submission Date: 03-08-2020;

- Review completed: 06-09-2020;

- Accepted Date: 11-09-2020.

DOI : 10.5530/pj.2020.12.235

Article Available online http://www.phcogj.com/v12/i6s

\section{Copyright}

(C) 2020 Phcogj.Com. This is an openaccess article distributed under the terms of the Creative Commons Attribution 4.0 International license.

\section{ABSTRACT}

Background: Phyllanthus amarus is a medicinal plant used in the treatment of various ailments which include gonorrhoea, jaundice, diabetes, kidney diseases, bladder and intestinal infections, influenza, measles, viral infections, and tuberculosis. Tuberculosis treatment is faced with many challenges, resulting in a prolonged treatment regimen and potential treatment failure. There is a need to search for more favourable treatment options. Objective: This study aimed at investigating the pharmacognostic and mycobactericidal properties of $P$. amarus. Since toxicity could also be an issue, the mutagenic activity of this plant was also assessed. Materials and Methods: The macroscopic, microscopic, and physicochemical characteristics were assessed with reference to the Quality Control Methods for Herbal Material WHO (2011). The mycobactericidal activity was determined by the agar diffusion and broth dilution methods, while mutagenicity was investigated by the Ames test. Results: $P$. amarus contained tannins, flavonoids, glycosides, saponins and steroids. The $50 \%$ ethanol extract exhibited activity against $M$. smegmatis at $100 \mathrm{mg} / \mathrm{mL}$ with an inhibitory zone of 2.0 $\mathrm{cm}$. P. amarus had a minimum inhibitory concentration of $50 \mathrm{mg} / \mathrm{mL}$ while that of rifampin was $0.1 \mu \mathrm{g} / \mathrm{mL}$. P. amarus showed weak mutagenicity at a concentration of $10 \mu \mathrm{g} / \mathrm{mL}$. Conclusion: The documented pharmacognostic characteristics can be used for quality control of the crude plant material. The mycobactericidal activity also affirmed its folkloric use in the treatment of tuberculosis. The mycobactericidal activity can be further exploited for drug development. Key Words: P. amarus, Pharmacognostic, Mutagenic activity, Tuberculosis, Fluorescence.

\section{INTRODUCTION}

Phyllanthus amarus Schum. \& Thonn is a plant belonging to the Euphorbiaceae family and is widely distributed across tropical and subtropical countries. This plant is known in English as black catnip, carry me seed, child pick-a-back, among many other names. ${ }^{1}$ It is currently found in many countries including India, Philippines, Cuba, Brazil, Ghana, Ivory Coast, Kenya, and Nigeria Etc. ${ }^{2-4} P$. amarus is an erect perennial herb not reaching one and a half foot tall having small leaves and yellow flowers. ${ }^{5}$ The appearance of dioecious cymes at the end of the branches are considered to be a distinct characteristic, in many respects it highly resembles its close relatives, $P$. debilis and $P$. fraternus of the same Swartziani sub-section. ${ }^{6,7}$ The genus Phyllanthus (Euphorbiaceae) consists of about 6500 species in 300 genera, of which 200 are American, 100 African, 70 from Madagascar and the remaining Asian and Australasian. ${ }^{8}$ The name 'Phyllanthus' means "leaf and flower" because the flower, as well as the fruit, seems to become one with the leaf. ${ }^{9}$ P. amarus has long been used worldwide in traditional folkloric medicine for treating a myriad of diseases including irregular menstruation, gonorrhoea, diabetes, urinary and intestinal infections, alleviation of kidney and gallbladder stones, influenza, measles, tuberculosis, liver diseases and disorders like hepatitis, jaundice and liver cancer. ${ }^{2,45,10}$ It is also used in treating hepatotoxicity, boosting the immune system, and active against hepatitis A. ${ }^{11}$ In Ayurveda medicine, P. amarus is also used for dropsy, arthritis, jaundice, asthma and bronchial infections. ${ }^{12}$ The whole plant material is also used for menorrhagia, genital illnesses, gastropathy, diarrhoea, dysentery, intermittent fevers, ophthalmopathy, scabies, ulcers and wounds. It is also used as a good tonic. ${ }^{13}$

P. amarus is known to biosynthesize many groups of naturally occurring compounds of medicinal importance. Its phytoconstituents include alkaloids, flavonoids, hydrolysable tannins, triterpenes, lignans, polyphenols, alkaloids, sterols, and oils. ${ }^{7}$ ${ }^{14}$ Many lignans have been isolated from this plant; phyllanthin and hypophyllanthin. Other lignans isolated from $P$. amarus are niranthin, phyltetralin, nirtetralin, isonirtetralin, hinokinin, lintetralin, isolintetralin, demethylenedioxy-niranthin and 5-demethoxyniranthin. Flavonoïds such as rutin, gallocatechin, kaempferol and various flavonoid glycosides have been isolated from this plant. The present in this plant material sellagitannins include geraniinic acid $\mathrm{B}$, geraniin, amariin, amarulone furosin, amariinic acid, phyllanthusiin A, B, C, D and melatonin. The securinega-type alkaloids isolated include epibubbialine and isobubbialine. The sterols also present in this plant include amarosterol A and amarosterol B. ${ }^{7-14}$ The extracts and compounds isolated from $P$. amarus have been shown to possess antibacterial, antiviral, antiplasmodial, antimalarial, 
antimicrobial, anti-inflammatory, anticancer, hypolipidemic, antidiabetic, antioxidant, nephroprotective, hepatoprotective, diurectic, anti-diarrheal, antiulcer, antifungal, analgesic, anti-allodynic, anti-oedematogenic, antinociceptic, antiplasmodial, and antiviral

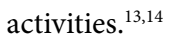

\section{MATERIALS AND METHODS}

\section{Plant collection}

The leaves of $P$. amarus were collected from the campus of the Kwame Nkrumah University of Science and Technology in January 2017 and authenticated by Mr. Asare of the Department of Pharmacognosy. A herbarium voucher with specimen number of PSM64/1/17 has been deposited at the institution's herbarium. The leaves were air-dried for two weeks and milled into a coarse powder.

\section{Macroscopic and microscopic analysis}

The leaves of $P$. amarus were examined macroscopically for characteristics such as colour, shape, texture, leaf venations and leaf margin. ${ }^{15}$ The microscopic characteristics of the leaves were studied following the standard protocols of the WHO guidelines on Quality Control Methods for Herbal Materials, 2011. ${ }^{15}$ Four-millimetre square $\left(4 \mathrm{~mm}^{2}\right)$ sizes of the mature lamina were cut. These were then boiled for about two hours in a solution of chloral hydrate. The sections were in glycerin and covered with a glass slip. The slides were observed with a LECIAD light microscope under low power and high power magnifications of $\times 10$ and $\times 40$. The mounts were observed for the presence of calcium oxalate crystals, stomata and trichomes were observed. Quantitative parameters such as vein islet number, veinlet termination numbers, stomatal number and stomatal index were determined. This was done by counting each determination under ten different fields of view and calculating the number per millimetre square of each leaf surface.

\section{Physico-chemical analysis}

Air-dried samples of $P$. amarus were analyzed for their physicochemical parameters. The loss on drying method estimated the moisture content. Total ash, acid insoluble ash and water-soluble ash were also determined using the WHO, 2011 guidelines. ${ }^{15}$

\section{Extractive values determination}

Twenty grams (20 g) of coarsely powdered air-dried leaves of plant material was weighed and $200 \mathrm{~mL}$ of water, $50 \%$ ethanol or petroleum ether was separately added to each sample. The plant materials were also sonicated for 45 minutes. The filtrates were obtained and concentrated in vacuo at $40^{\circ} \mathrm{C}$. The concentrates were then freeze-dried to obtain dry crude extracts and stored at $-20{ }^{\circ} \mathrm{C}$ prior to use. The percentage yields of petroleum ether, water and $50 \%$ ethanol were calculated with reference to the air-dried material.

\section{Phytochemical screening}

The crude plant material and extracts of $P$. amarus were screened phytochemically for the presence of tannins, glycosides, saponins, alkaloids and flavonoids using standard methods. ${ }^{16,17}$

\section{Fluorescence studies}

Fluorescence analysis of the powdered crude drug was carried out to determine the characteristic fluorescence. The pulverized leaf sample was dissolved in specific solvents according to methods described by Ranjith, 2018.18 Observations were also carried out under visible daylight, UV light of short wavelength $(254 \mathrm{~nm})$ and UV light of long wavelength $(365 \mathrm{~nm})$ for resultant characteristic colour. ${ }^{18}$ The solvents employed were distilled water, $1 \mathrm{~N} \mathrm{HCl}, 1 \mathrm{~N} \mathrm{NaOH}, 50 \% \mathrm{H}_{2} \mathrm{SO}_{4}$, methanol, glacial acetic acid, nitric acid, chloroform, 50\% $\mathrm{FeCl}_{3}$ and $96 \%$ ethanol.

\section{Determination of mycobactericidal activity}

\section{Test organism}

Mycobacterium smegmatis (MC2 155) was obtained from the Noguchi Memorial Institute for Medical Research (NMIMR), University of Ghana. Middlebrook 7H9 powder (VWR, U.S.A.) was used for cultivation. A loopful of $M$. smegmatis culture was introduced into 20 $\mathrm{mL}$ of $7 \mathrm{H} 9$ Middlebrook broth and incubated for 24 hours at $37^{\circ} \mathrm{C}$. The bacterial culture was then standardized to contain $1 \times 10^{6} \mathrm{cell} / \mathrm{mL}$ by the help of a previously calibrated bacterial suspension curve at $680 \mathrm{~nm}$ using a calorimeter.

\section{Agar well diffusion method}

A concentration of $100 \mathrm{mg} / \mathrm{mL}$ of each of the water, $50 \%$ ethanol and petroleum ether extracts were prepared in sterile distilled water and sterile filtered through a $0.22 \mu \mathrm{M}$ membrane filter.

A hundred microliters $(100 \mu \mathrm{L})$ of $1 \times 10^{6}$ cell $/ \mathrm{mL}$ culture of $M$. smegmatis was added to $20 \mathrm{~mL}$ of nutrient agar, stabilized at $45^{\circ} \mathrm{C}$, mixed, poured into a sterile petri dish and the agar allowed to set. Five holes were bored equidistant from each other using a sterile cork borer of diameter $13 \mathrm{~mm}$ (Number 6). A volume of $150 \mu \mathrm{L}$ of each extract was introduced into a separate well. Sterile water of $150 \mu \mathrm{L}$ was introduced into the fourth well as the untreated control, and 150 $\mu \mathrm{L}$ of rifampicin $(10 \mu \mathrm{g} / \mathrm{mL})$ was introduced into the fifth well as the positive control. The extracts were allowed to diffuse for 15 minutes at room temperature, and thereafter incubated at $37^{\circ} \mathrm{C}$ for 24 hours. The diameter of the zones of inhibition was measured. The experiment was performed in triplicates.

\section{Determination of Minimum inhibitory concentration}

The active extracts (aqueous and 50\% ethanol), were assessed for their MIC. Two hundred milligram per millilitres $(200 \mathrm{mg} / \mathrm{mL})$ concentration of the active $50 \%$ ethanol leaf extract of $P$. amarus was prepared. A volume of $500 \mu \mathrm{L}$ of double strength nutrient broth, $250 \mu \mathrm{L}$ of plant extract, $50 \mu \mathrm{L}$ of sterile water and $200 \mu \mathrm{L}$ of bacterial culture were added to a 24 well plate to produce a concentration of $100 \mathrm{mg} /$ $\mathrm{mL}$. Another $500 \mu \mathrm{L}$ of double strength (D/S) nutrient broth, $125 \mu \mathrm{L}$ of extract, $175 \mu \mathrm{L}$ of sterile water and $200 \mu \mathrm{L}$ of culture were added to the next well to make a concentration of $50 \mathrm{mg} / \mathrm{mL}$. Double strength nutrient broth $(500 \mu \mathrm{L}), 62.50 \mu \mathrm{L}$ plant extract, $237.5 \mu \mathrm{L}$ of sterile water and $200 \mu \mathrm{L}$ culture was added to another well to make a concentration of $25 \mathrm{mg} / \mathrm{mL}$. A growth control was set up with $500 \mu \mathrm{L}$ of D/S nutrient broth, $300 \mu \mathrm{L}$ sterile water and $200 \mu \mathrm{L}$ culture added together in a well. The negative control contained $500 \mu \mathrm{L} \mathrm{D} / \mathrm{S}$ nutrient broth, $250 \mu \mathrm{L}$ plant extract and $250 \mu \mathrm{L}$ sterile water. The well plates were incubated at $37^{\circ} \mathrm{C}$ for 24 hours and observed. A concentration of $0.004 \mu \mathrm{g} / \mathrm{mL}$ of rifampin was used as a positive control. To $500 \mu \mathrm{L}$ of $\mathrm{D} / \mathrm{S}$ nutrient broth was added $250 \mu \mathrm{L}$ of rifampin, $50 \mu \mathrm{L}$ sterile water and $200 \mu \mathrm{L}$ culture were added in one well to make $10 \mu \mathrm{g} / \mathrm{mL}$. Also, $500 \mu \mathrm{L} \mathrm{D} / \mathrm{S}$ nutrient broth, $25 \mu \mathrm{L}$ rifampin, $275 \mu \mathrm{L}$ sterile water and $200 \mu \mathrm{L}$ were added to the next well to make $1 \mu$ gmL. Finally, $500 \mu \mathrm{L}$ DS nutrient broth, $2.5 \mu \mathrm{L}$ rifampicin, $297.5 \mu \mathrm{L}$ sterile water and $200 \mu \mathrm{L}$ were added to the next well. It was incubated at the same conditions. Each experiment was carried out in triplicates.

\section{Determination of kill kinetics}

Using the method described by Gbedemah et al., 2010 ${ }^{19}$, midlogarithmic phase cultures of $M$. smegmatis were transferred into 50 $\mathrm{mL}$ portions of pre-warmed nutrient broth containing twice the MIC of the ethanol extract $(100 \mathrm{mg} / \mathrm{mL})$, to yield final concentrations of 
$1 \times 10^{6}$ cell $/ \mathrm{mL}$. The broths were maintained in a stabilized water bath at intermittent shaking. Aliquots $(1 \mathrm{ml})$ were drawn after $0,1,2,3$, $4,5,6,12$ and $24 \mathrm{~h}$ and diluted in another $10 \mathrm{~mL}$ nutrient broth to neutralize the effect of the extract. Viable counts were then determined by the pour plate method. One millilitre $(1 \mathrm{~mL})$ of the diluted culture suspensions was added to a sterile petri dishe, and $20 \mathrm{~mL}$ of molten nutrient agar, stabilized at $45^{\circ} \mathrm{C}$ was poured over it and shaken. Growth controls were also set up in the nutrient broth. Same was done for 0.4 $\mu \mathrm{g} / \mathrm{mL}$ rifampicin as the positive control. All plates were then incubated inverted at $37^{\circ} \mathrm{C}$ for 24 hours, after which the number of viable cells was counted. All experiments were performed in triplicates. Survivors were estimated by counting the number of colonies. Survivor-time curves were drawn for the test organisms, exposed to the extract and controls. A graph of log of the number of viable cells against time was plotted and analyzed using 2 - way ANNOVA, Bonferroni post-test.

\section{Determination of mutagenicity}

The aqueous extract of $P$. amarus was dissolved in sterile water on the day of the assay, to give a concentration of $10 \mu \mathrm{g} / \mathrm{mL}$ and sterile filtered using a $0.22 \mu \mathrm{M}$ membrane filter. The Muta-ChromoPlate ${ }^{\mathrm{TM}}$ two strain kit (Environmental Bio-Detection Products Inc, Ontario, Canada) which works on the principle of the Ames test was employed to determine the mutagenicity potential of the extracts. ${ }^{20}$ The experiment was carried out under the protocol provided by the manufacturer using Salmonella typhimurium TA98 strain. The experiment was performed similarly to methods already published in the literature. ${ }^{21}$ The number of positive wells scored in the 96 well plates determined the significance of mutation in the fluctuation test..$^{22}$ The statistical table provided in the kit was used to compare the natural background rate of reverse mutation to the rate of reverse mutation within a sample assay. Based on these samples, $\mathrm{p}$ values of 0.001 were classified as highly mutagenic, $p$ values of 0.01 moderately mutagenic and $p$ values of 0.05 weakly mutagenic.

\section{RESULTS}

\section{Macroscopic characteristics}

Organoleptic examination of the leaves of $P$. amarus showed that it was deep green and had non-specific odour and tastes. A summary of these features is given in Table 1. P. amarus consists of pinnate compound leaves which are alternately arranged on the stem (Figure 1). The leaflets were oblong to elliptical, had entire margins reticulate venation, and glabrous surfaces. On the lower side of each rachis, small, ovoid fruitlets arranged in a row were observed.

\section{Microscopic characteristics}

The microscopic analysis involved the qualitative observations and the quantitative investigations, also known as leaf constants. The vein islet number was calculated to be 10 per $\mathrm{mm}^{2}$. Veinlet terminations were calculated as 6 per $\mathrm{mm}^{2}$. Details of the results are shown in Table 2 . Internally, $P$. amarus leaves showed the presence of wavy epidermal cells, paracytic stomata, prismatic calcium oxalate crystals which were lined up along the veins. The reticulate veins can be categorised as dichotomizing with poorly developed areoles (Figure 2).

\section{Physicochemical characteristics}

The physico-chemial parameters of the leaves of $P$. amarus are provided in Table 3. The water-soluble ash content was of $13.5 \% \mathrm{w} / \mathrm{w}$, followed by the total ash content of $6.17 \% \mathrm{w} / \mathrm{w}$, and acid insoluble ash value of $5.67 \% \mathrm{w} / \mathrm{w}$. The average moisture content was approximately $14 \% \mathrm{w} / \mathrm{w}$. $P$. amarus had the highest extract yield in the $50 \%$ ethanol solvent and the least amount in petroleum ether (Table 4).

\section{Fluorescence analysis}

Analysis for characteristic fluorescence of the samples at short and long wavelengths showed varying colours for all the samples. These results

Table 1: Macroscopic characteristics of $P$. amarus leaf.

\begin{tabular}{cc}
\hline Morphology & P. amarus \\
\hline Shape & Oblong \\
Margin & Entire \\
Venation & Pinnately reticulate \\
Texture & Smooth \\
Type & Compound leaf \\
\hline
\end{tabular}
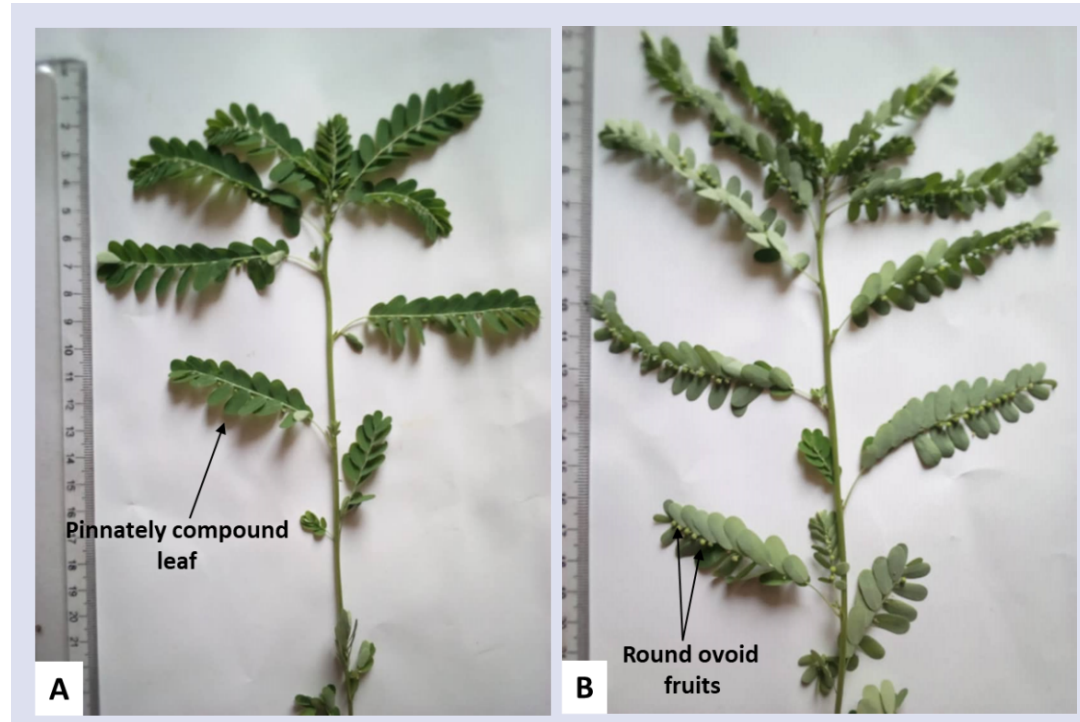

Figure 1: Phyllanthus amarus plant. A shows compound leaves with pinnately arranged Leaflets. B shows an array of fruits on the lower side of the leaf rachis. 


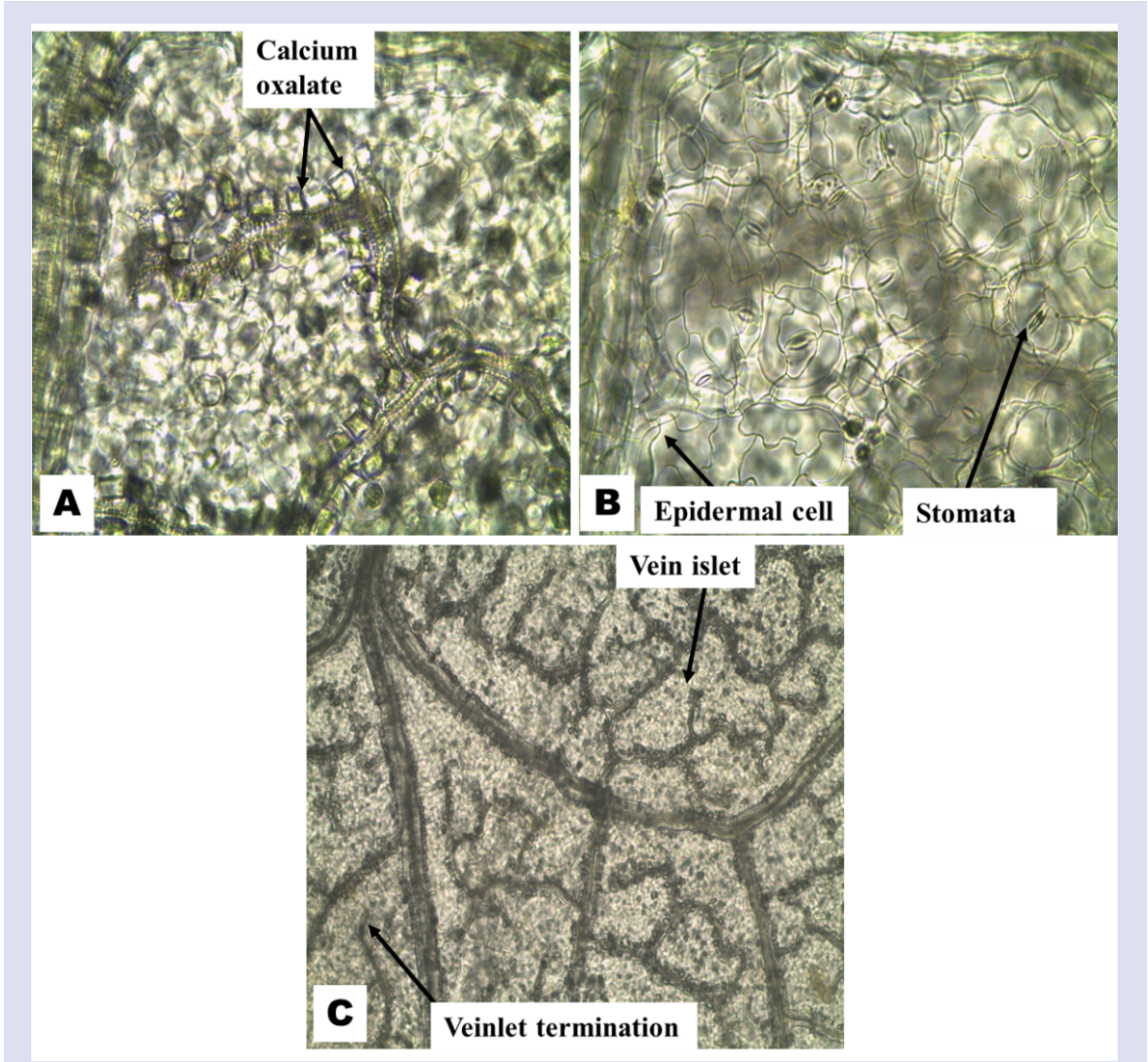

Figure 2: Microscopic characteristics of the leaf surface of $P$. amarus. A. Prismatic calcium oxalate crystals B. Epidermal cells and stomata C. Vein islets and veinlet terminations.

\section{Table 2: Microscopic characteristics of $P$. amarus.}

\begin{tabular}{cc} 
Parameter & P. amarus \\
\hline Stomatal Number & $5 \pm 2.8$ \\
Epidermal Cell Number & $35 \pm 2.0$ \\
Vein islet Number & $10 \pm 1.7$ \\
Veinlet termination number & $6 \pm 1.9$ \\
The stomatal index [stomata per square mm of epidermis] & $12.5 \pm 2.1$ \\
\hline
\end{tabular}

Table 3: Physicochemical characteristics of $P$. amarus.

\begin{tabular}{cc}
\hline Parameters & P. amarus \\
\hline Total ash & $6.17 \pm 1.2$ \\
Acid insoluble ash & $5.67 \pm 1.5$ \\
Water soluble ash & $13.50 \pm 1.4$ \\
Moisture content & $13.67 \pm 2.1$ \\
Foreign organic matter & - \\
Foaming index & $<100$ \\
Swelling index $[\mathrm{mL}]$ & $7.33 \pm 2.2$ \\
\hline
\end{tabular}

Table 4: Extractive values.

\begin{tabular}{cc}
\hline Solvent & P. amarus (\% W/W) \\
\hline Water & $11.29 \pm 2.2$ \\
Ethanol 50\% & $20.76 \pm 1.5$ \\
Petroleum Ether & $7.00 \pm 1.8$ \\
\hline
\end{tabular}


are useful for both identity and quality determination of the samples. These are presented in Tables 6.

\section{Mycobactericidal activity}

When $100 \mathrm{mg} / \mathrm{mL}$ concentrations of the water, $50 \%$ ethanol and petroleum ether extracts of $P$. amarus was screened for preliminary mycobactericidal activity, the water and $50 \%$ ethanol extracts showed activity against $M$. smegmatis with a zone of inhibition of $1.5 \pm 0.2$ and $2 \mathrm{~cm} \pm 0.5$ respectively. $P$. amarus had a MIC of $50 \mathrm{mg} / \mathrm{mL}$ and 100 $\mathrm{mg} / \mathrm{mL}$ for the $50 \%$, ethanol and aqueous extracts respectively, while rifampin had an MIC of $0.1 \mu \mathrm{g} / \mathrm{mL}$. Kill kinetics studies of the $100 \mathrm{mg} /$ $\mathrm{mL} 50 \%$ ethanol extract showed a significant reduction in the number of cells over 24-hour period. This was also observed for rifampicin as shown in Figure 3 . The area under each curve was also significantly reduced when compared to the untreated control.

\section{Mutagenic activity}

The Ames test showed the aqueous extract of $P$. amarus to be weakly mutagenic.

\section{DISCUSSION/CONCLUSION}

The discovery and development of new antimicrobials is a significant health challenge in dealing with infections caused by especially multidrug-resistant bacteria such as the mycobacteria. ${ }^{23}$ It is, therefore, imperative that new sources of drugs are developed. Plant sources have made significant contributions to the development of new drugs since the beginning of modern medicine. ${ }^{24}$

The studied pharmacognostic characteristics of $P$. amarus are a prerequisite for standardization. ${ }^{25}$ These characteristics can be used as a good indication of identity, purity and quality ${ }^{26}$ and provide a means of detecting adulteration and substitution of this plant material. $P$. amarus is used in the treatment of numerous ailments, ${ }^{2,4,5,10,26}$ including tuberculosis hence these the pharmacognostic and mycobactericidal results will go a long way to assure the safe and efficacious use of this plant material.

Table 5: Preliminary phytochemical screening of secondary metabolites of P. amarus.

\begin{tabular}{cc}
\hline Constituent & Results \\
\hline Saponins & + \\
Alkaloids & + \\
Flavonoids & + \\
Tannins & + \\
Steroids & + \\
Glycosides & + \\
\hline
\end{tabular}

+: Present; -: Absent

Table 6: Fluorescence studies of powdered $\boldsymbol{P}$. amarus leaves in various solvents.

\begin{tabular}{|c|c|c|c|}
\hline & Daylight & $254 \mathrm{~nm}$ & $365 \mathrm{~nm}$ \\
\hline $\begin{array}{l}\text { Powdered Sample } \\
\text { only }\end{array}$ & Greenish brown & Dark brown & Brown \\
\hline Distilled water & Brown & Purple & Purple \\
\hline $1 \mathrm{~N} \mathrm{HCl}$ & Green & Purple & Pale purple \\
\hline $1 \mathrm{~N} \mathrm{NaOH}$ & Red & Purple & Pale purple \\
\hline $10 \mathrm{~N} \mathrm{H}_{2} \mathrm{SO}_{4}$ & Deep green & Blue & Blue \\
\hline Methanol & Pale brown & Red & Pale blue \\
\hline Glacial acetic acid & Pale brown & Red & Pale blue \\
\hline Nitric acid & Yellow & Blue & Pale blue \\
\hline Chloroform & Brown & Red & Paler red \\
\hline $50 \% \mathrm{FeCl}_{3}$ & Black & Deep blue & Pale blue \\
\hline $96 \%$ Ethanol & Light green & Red & Pale blue \\
\hline
\end{tabular}
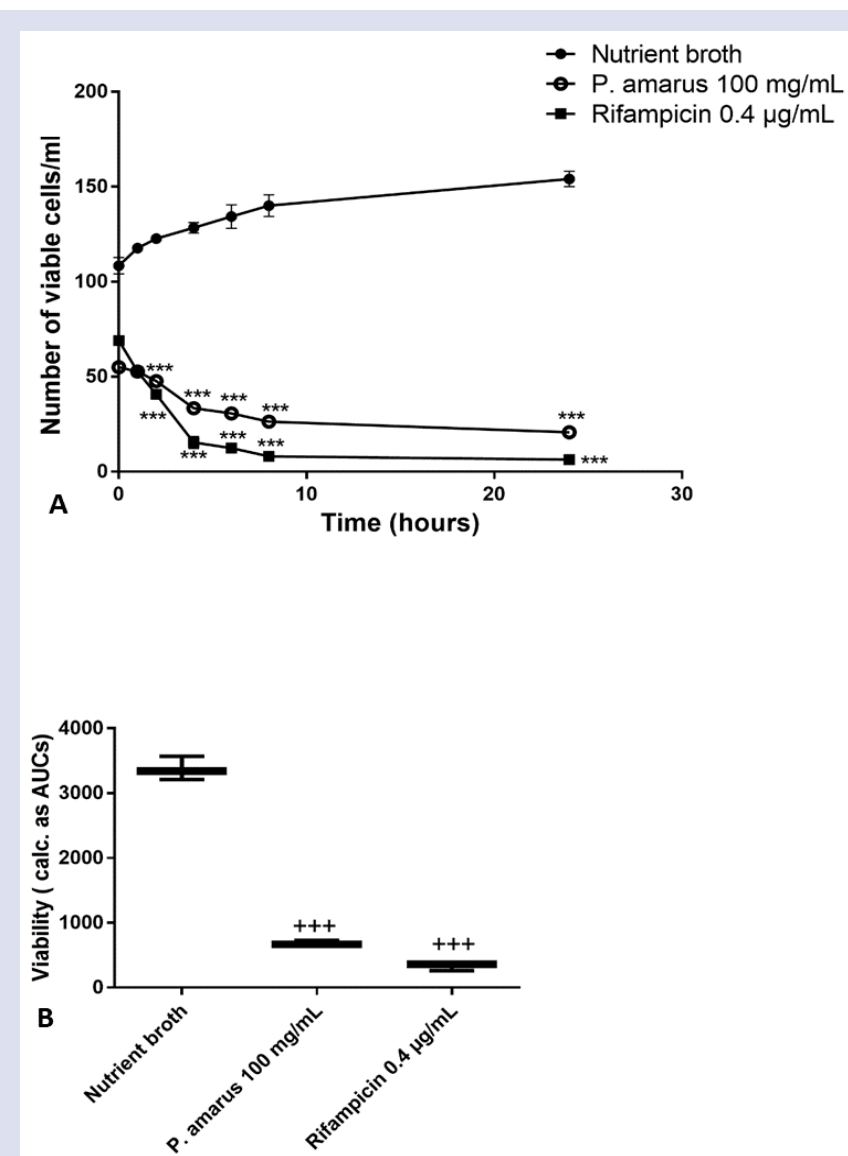

Figure 3: Time-kill kinetics of $50 \%$ ethanol extract of $P$. amarus leave on M. smegmatis. A: time-kill kinetics curve, B: Area under curve of timekill kinetics. Values are mean $\pm S E M, n=3$. ${ }^{* * *} p<0.001$ compared to the growth control (One-way ANOVA followed by Dunnett's post hoc test).

The macroscopic and microscopic examinations of the medicinal plant have served as tools for distinguishing between closely related species. They also enable the discovery of essential characteristics of species, thus preventing adulteration..$^{27}$ In the present study, the morphological features observed, were consistent with the literature. ${ }^{28}$ Also, microscopic observations such as anisocytic stomata, wavy epidermal cells and prismatic calcium oxalate crystal are similar to finding made by Sharma and Sheela (2011). ${ }^{29}$ Measuring the ash values of the plant can give an idea of the presence of inorganic constituents and other impurities that may be present in the plant material. Acid insoluble ash gives a measure of the amount of silica present, especially in the form of sand and siliceous earth. ${ }^{30}$ The water- soluble ash content was $13.5 \% \mathrm{w} / \mathrm{w}$, followed by the total ash content of $6.17 \% \mathrm{w} / \mathrm{w}$, and acid insoluble ash value of $5.67 \% \mathrm{w} / \mathrm{w}$. These extractive values are similar to that already published. ${ }^{31}$ In which the total ash, water-soluble ash and acid-insoluble were reported to be $7.5,9-12,4-9 \% \mathrm{w} / \mathrm{w}$ respectively. The slight variations may likely be due to environmental factors. ${ }^{32}$

The total ash corresponds to the total quantity of physiological ash results from mineral components of the plant tissues as well as and non-physiological ash due to extraneous content such as sand and soil that could have been present in the collected plant sample. ${ }^{33}$ The total ash value aids in the detection of low-grade products and the establishment of purity characteristics. ${ }^{33,34}$ The water-soluble ash, which was $13.5 \%$, on the other hand, corresponds to the ash produced from the water extract of the plant material, this value could be used to detect previously extracted plant materials. The acid insoluble ash, which was determined to be $5.7 \%$ also gives the amount of inorganic material such as silica or metals that could be present. A significant increase or 
decrease in this value could indicate that plant material that could have been contaminated or adulterated. The average moisture content was approximately $14 \% \mathrm{w} / \mathrm{w}$, which is significantly lower than that reported by Dhongade and Chandewar, 2013. ${ }^{31}$ A higher moisture content could indicate the presence of excess moisture and hence degradation. Low moisture content is indicative of better stability against degradation of the herbal material..$^{30}$ Extractive values indicate weights of the extractable chemical constituents of the crude drug under different solvents environment. ${ }^{30}$ Per the results obtained, the leaves of $P$. amarus contained a high proportion of middle polar constituents.

The presence of alkaloids, flavonoids, tannins, steroids, saponins, glycosides as seen in P. amarus is already in accordance with the published literature. ${ }^{31}$

When herbal materials contain appreciable amounts of saponins, there is a persistent foam when an aqueous decoction is shaken. ${ }^{15}$ The foaming index was determined to be less than a 100 for all the aqueous decoction, indicating possibly the presence of a low concentration of saponins. ${ }^{15}$

The pulverised leaf gives a characteristic red and purple fluorescence in several solvents and reagents under UV light of both short and long wavelength (Table 6). These fluorescent behaviour can be a useful tool in further confirming the purity of crude plant materials from this plant. The pulverised leaf suspended in ethanol is shown to be light green, red and pale blue under daylight, 254 and 365 UV light respectively. The ethanol extract is, however, reported to be yellow, brown and light green, respectively. ${ }^{31}$

For studies on the mycobactericidal activities of $P$. amarus leaves, M. smegmatis, a soil-dwelling saprophyte related to Mycobacterium tuberculosis was employed. It is a mycobacterium model that is used to understand the pathogenesis of $M$. tuberculosis because of the disadvantages in the direct use of the disease-causing tubercle bacillus. ${ }^{35}$ Both the aqueous and $50 \%$ ethanol extracts of $P$. amarus showed activity. However, the ethanol extract had higher activity evident by a larger zone of inhibition. The zones of inhibition is indicative of the presence of antimicrobial constituents. The minimum inhibitory concentration was determined as $50 \mathrm{mg} / \mathrm{mL}$ and $100 \mathrm{mg} / \mathrm{mL}$ for the $50 \%$ ethanol and aqueous extract, respectively. This high MIC suggests the need for further optimization to determine active fractions and compounds. Further analysis of the active $50 \%$ ethanol extracts at 100 $\mathrm{mg} / \mathrm{mL}$ in kill kinetic studies, showed a significant reduction in the number of viable cells as compared to that of the untreated control at all time points over a 24-hour period. Antimicrobial plants are known to act alone, synergistically or as potentiators to already existing drugs. ${ }^{36}$ When antimicrobial plant extracts are used in therapy, they could reduce the immergence of resistant strains. ${ }^{37}$ Hence the identified mycobactericical activity of $P$. amarus can be further optimized for the treatment of tuberculosis. This preliminary activity also authenticates the folkloric use of this plant in the treatment of tuberculosis. ${ }^{10}$

In the mutagenic studies, $P$. amarus was weakly mutagenic. Mutation in the S. typhimurium TA 98 strain used in this study is indicative of a frameshift mutation; this could, therefore, infer that this plant could contain components that can intercalate between the normal bases to create mistakes during DNA synthesis. ${ }^{38}$ However, this needs to be further investigated.

In conclusion, the determined pharmacognostic indices can be employed to determine the authenticity, purity and quality of $P$. amarus. The mycobacterial activity of $P$. amarus against $M$. smegmatis is promising; hence this plant can be further exploited for the development of alternative treatments for mycobacterial infections. The mutagenic results for $P$. amarus suggest that this plant may need to be used with caution and further screened for toxicity.

\section{ACKNOWLEDGEMENTS}

The authors will like to acknowledge Mr. Clement Sasu and Mrs. Akosua Okraku of Department of Pharmaceutics and Microbiology as well as Miss Hannah Amponsah and Francis Setsofia of the Department of Pharmacognosy and Herbal Medicine all of the School of Pharmacy, University of Ghana for their technical assistance when performing the experiments.

\section{CONFLICTS OF INTEREST}

None.

\section{ABBREVIAITONS}

MIC: Minimum inhibitory concentration.

\section{REFERENCES}

1. Meena J, Sharma RA, Rolania R. A Review on Phytochemial and Pharmacological Properties of Phyllanthus amarus Schum. and Thonn. Int J Pharm Sci Res, 2017;5:1377-86.

2. Calixto JB, Santos AR, Filho VC, Yunes RA. A review of the plants of the genus Phyllanthus: their chemistry, pharmacology, and therapeutic potential. Med. Res. Rev, 1998;18(4):225-58.

3. cheampong DO, Owusu-Adzorah N, Armah FA, Aninagyei E, Asiamah EA Thomford AK, et al. Ethnopharmacological evaluation of schistosomicidal and cercaricidal activities of some selected medicinal plants from Ghana Trop Med Health, 2020;48:19.

4. Jantan I, Haque MA, llangkovan M,Arshad L. An Insight Into the Modulatory Effects and Mechanisms of Action of Phyllanthus Species and Their Bioactive Metabolites on the immune System. Front. Pharmacol, 2019;10:1-19.

5. Okafor PC, Ikpi ME, Uwah IE, Ebenso EE, Ekpe UJ,Umoren SA. Inhibitory action of Phyllanthus amarus extracts on the corrosion of mild steel in acidic media. Corros. Sci, 2008;50(8):2310-7.

6. Mitra ML,Jain SK. Concept of Phyllanthus niruri (Euphorbiaceae) in Indian Floras. Bull. Bot. Surv. India, 1985; 27:161-76.

7. Row LR, Satyanarayana P,Rao GS. Crystalline constituents of euphorbiaceaeVI: The synthesis and absolute configuration of phyllanthin. Tetrahedron, 1967;23(4):1915-8.

8. Govaerts R, Frodin DG, Radcliffe-Smith A,Carter S. World checklist and bibliography of Euphorbiaceae (with Pandaceae). 2000: Royal Botanic Gardens, Kew.

9. Ogbodo EC, Emeka NC, Ezeugwunne IP, Analike RA, DiKe CC, Njoku CM, et al Effect of Ethanoic Leaf Extract of Phyllantus Amarus on Fasting Blood Glucose, Bilirubin, Albumin and Total Protein on Diabetic Induced Albino Wistar Rats in College Of Health Sciences, Nnamdi Azikiwe University, Nnewi Campus, Anambra State, Nigeria. GSJ, 2017;5(7):78

10. Unander DW, Webster GL,Blumberg BS. Usage and bioassays in Phyllanthus (Euphorbiaceae) IV. Clustering of antiviral uses and other effects. J. Ethnopharmacol 1995;45:1-18.

11. Negi As, Kumar JK, Luqman S, Shanker K, Gupta MM,Khanuja SP. Recent advances in plant hepatoprotectives: a chemical and biological profile of some important leads. Med. Res. Rev, 2008;28(5):746-72.

12. Lim ZZ,Murtijaya J. Antioxidant properties of Phyllanthus amarus extracts as affected by different drying methods. LWT-FOOD SCI TECHNOL, 2007;40(9):1664-9.

13. Patel JR, Tripathi P, Sharma V, Chauhan NS, Dixit VK. Phyllanthus amarus: ethnomedicinal uses, phytochemistry and pharmacology: a review. J. Ethnopharmacol, 2011;138(2):286-313

14. Patela JR, Tripathib P, Sharmaa V, Chauhana NS, Dixita VK. Phyllanthus amarus: Ethnomedicinal uses, phytochemistry and pharmacology: A review. J. Ethnopharmacol, 2011; 138:286-313.

15. WHO. Quality control methods for herbal materials. World Health Organization, Geneva, Switzerland. 2011.

16. Khandelwal KR. Practical Pharmacognosy Techniques and Experiments. 2002 New Delhi: Nirali Prakashan.

17. Harborne J.B. . Phytochemical methods. 1992, London: Chapman and Hall Publications.

18. Ranjith D. . Fluorescence analysis and extractive values of herbal formulations used for wound healing activity in animals. Journal of Medicinal Plants Studies, 2018;6(2):189-92.

19. Gbedema SY, Emelia K, Francis A, Kofi A, Eric W. Wound healing properties and kill kinetics of Clerodendron splendens G. Don, a Ghanaian wound healing plant. Pharmacogn. Res, 2010;2(2):63. 
20. Ames BN, Mccann J,Yamasaki E. Methods for detecting carcinogens and mutagens with the Salmonella/mammalian-microsome mutagenicity test. Mutat Res. , 1975;31(6):347-64.

21. Oppong Bekoe E, Dodoo KB, Kitcher C, Gordon A, Frimpong-Manso S,Schwinger G. Pharmacognostic Characteristics and Mutagenic Studies of Alstonia boonei De Wild. RJP, 2020;7(1):7-15

22. Gilbert RI. The analysis of fluctuation tests. Mutat. Res, 1980;74(4):283-9.

23. Hughes D., Karlen A. Discovery and preclinical development of new antibiotics. Ups J Med Sci, 2014;119(2):162-9.

24. Wachtel-Galor S,Benzie IFF. Herbal Medicine: An Introduction to Its History, Usage, Regulation, Current Trends, and Research Needs, in Herbal Medicine: Biomolecular and Clinical Aspects. 2nd edition. 2011, Boca Raton (FL): CRC Press/Taylor \& Francis;

25. Chanda S. Importance of pharmacognostic study of medicinal plants: An overview. Journal of Pharmacognosy and Phytochemistry, 2014;2(5):69-73.

26. Hussain K, Majeed MT, Ismail Z, Sadikun A,P. Ibrahim. Traditional and complementary medicines: Quality assessment strategies and safe usage. South Med Rev, 2009;2(1):19-23.

27. Patwekar SLB, Suryawanshi AS, Gaikwad MS, Padewad SR,Potulwar AP. Standardization of Herbal drugs: An overview. International Research Journal of Pharmacy, 2011;2(12):56-60.

28. Verma S, Sharma H,Garg M. Phyllanthus Amarus: A review. Journal of Pharmacognosy and Phytochemistry, 2014;3(2):18-22.
29. Sharma SK, Sheela MA. Pharmacognostic evaluation of leaves of certain Phyllanthus species used as a botanical source of Bhumyamalaki in Ayurveda. 2011;32(2):250-3

30. Folashade $\mathrm{KO}$, Omoregie EH,Ochogu AP. Standardization of herbal medicines A review Int. J. Biodivers. Conserv, 2012;4(3):101-12.

31. Dhongade HJ, Chandewar AV. Pharmacognostical and Phytochemical studies of Phyllanthus amarus leaves IJBAR, 2013;04(06):382-9.

32. Ncube B, Finnie JF, Staden JV. Quality from the field: The impact of environmental factors as quality determinants in medicinal plants. S. Afr. J. Bot, 2012;82:11-20

33. Bello Abdullahi A, Adamu U, Sallau Muhammad S,Okunola Oluwole J. Physical and phytochemicals study of some local herbal remedies. OSR-J Pharm Bio Sci, 2015;10(4):5-10.

34. Oppong Bekoe E, Kitcher C, Amponsah Agyei G,Frimpong-Manso S Pharmacognostic Characteristics of Hibiscus sabdariffa L. as a Means of Monitoring Quality RJP, 2020;7(3):55-63.

35. Allotey-Babington G, Nettey H, Debrah P, Adi-Dako O, Sasu C, Antwi A, et al. Screening of Several Anti-Infectives for in Vitro Activity against Mycobacterium smegmatis. AiM, 2014;4(16):1197.

36. Abreu AC, McBain AJ,Simões M. Plants as Sources of New Antimicrobials and Resistance-Modifying Agents Nat Prod Rep 2012;29(9):1007-21.

37. Cheesman M. J., Ilanko A., Blonk B.,Cock I. E. Developing New Antimicrobial Therapies: Are Synergistic Combinations of Plant Extracts/Compounds with Conventional Antibiotics the Solution? Pharmacogn Rev, 2017;11(22):57-72.

38. Maron DM,Ames BN. Revised Methods for the Salmonella Mutagenicity Test Mutat. Res, 1983;113:173-215. 


\section{GRAPHICAL ABSTRACT}

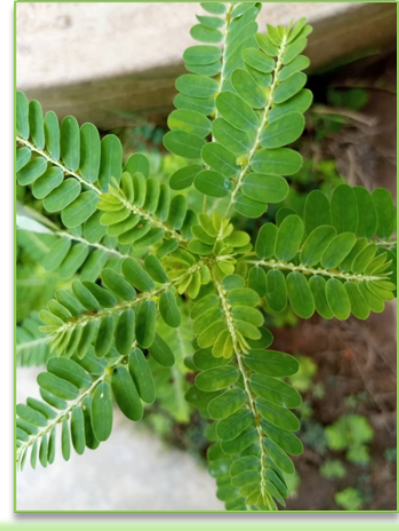

P. amarus

Pharmacognostics

Macroscopic, Microscopic,

Physicochemical, Flourescent

Mycobatericidal activity

Agar Well Diffusion Assay

Microbroth Dilution Method

\section{Mutagenic Investigations}

Ames Test

Pharmacognostic characteristics for quality control, Mycobacteria active,

Weakly mutagenic

Cite this article: Bekoe EO, Kitcher C, Debrah P, Amoateng P, Donkor PO, Martinson. A Study on Phyllanthus amarus; Pharmacognostic, Mycobactericidal and Mutagenic Properties. Pharmacogn J. 2020;12(6)Suppl:1732-9. 